\title{
小児における肋膜外ペースメーカー植込みの経験
}

信州大学第 2 外科学教室

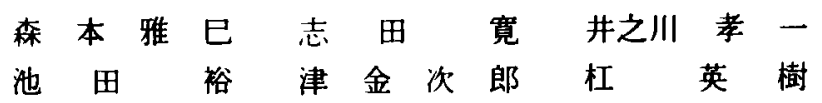

\section{EXPERIENCE OF EXTRAPLEURAL PACEMAKER IMPLANTATION FOR ATRIOVENTRICULAR BLOCK IN INFANTS}
Masami MORIMOTO, Hiroshi SHIDA, Koichi INOKAWA, Yutaka IKEDA, Jiro TSUGANE and Hideki YUZURIHA

The Second Department of Surgery, Shinshu University School of Medicine

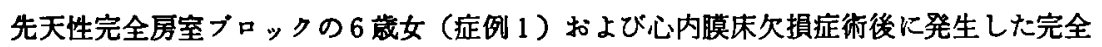
房室ブロックの12藏男（症例 2）に対して，肋膜外ペースィーカー植込みを行ったのでそ の経験を報告する、

手術方法は左開胸で心施電極を左室心尖部に栍着し、ベースメーカー本体は胸壁肋膜を 胸壁より别離して作製したポケットに収納・固定するものである. 症例 1 お。び 2 ともに ペースメーカー本体はリチゥム電池 (Intermedics model 223)，電極は小児用心筋電極 (CPI model 4311) を使用した，症例 1 は約 4 年後の現在まで，合併症を認めることな く順調に経過している. 症例 2 は約 3 年後, 電亟先端（tip）の断線を認めたため，新た に経静脈電極扰上び前胸壁植込みのペースメーカー植込みを行った．肋膜外べースメーカ 一本体の剔出には多少の困難が諗められた。電極断線は肋膜外植込みのためとは考えられ ず, 症例 2 においても肋膜外ベースメーカー植込みによる愁訴は全く認められなかった。

すなわち, 完全房室プロックの小児 ( 2 例) に肋膜外にポケットを作ってペースメーカ 一本体を植込み，ほほ満足すべき結果を得心，小児（乳幼児）に打けるべースメーカー本 体の植込み部位として，肋膜外は広く用いられてょいと考えられる。

墸 专

小児のベースメーカー (PM) 植込みは成人を巽なり 成長を伴うため, PM 器種, ペーシンク数および刺激 部位などの慎重な選択が必要である. 特に, PM 植込 み部位については成長および運動に伴って生じる電極断 線などの合併症の起り難い胸腔内が望ましいといわれて いる. われわれは先天性完全房室ブロックおよび外科的 完全房室ブロックの小児, それぞれ 1 例に対して, 助膜 外 PM 植込みを行ない，ほほ満足した結果が得られた ので，特に，小児の PM 植込み部位について若干の考 察を加えて報告する。

\section{症例}

症例 1

思者 : 6 歳, 女.

家族歷，既往歴：特記すべきことはない。

現病憷：出産時就よび乳児検䛦時に徐脈を指摘された ことはない，成長は標準範囲で，運動も普通に行ってい た. 昭和51年12月，感昌に罹患した時に，初めて徐脈を 指摘された. 昭和52年 2 月, Adams-Stokes 発作を起こ し，某病院に緊急入院した，isopreternol の投与，続い て一時的ベーシングを受けてから当科に入院した。

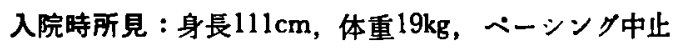
時の自己心拍数は38/分, 整. 血圧118/58mmHg. チフ 


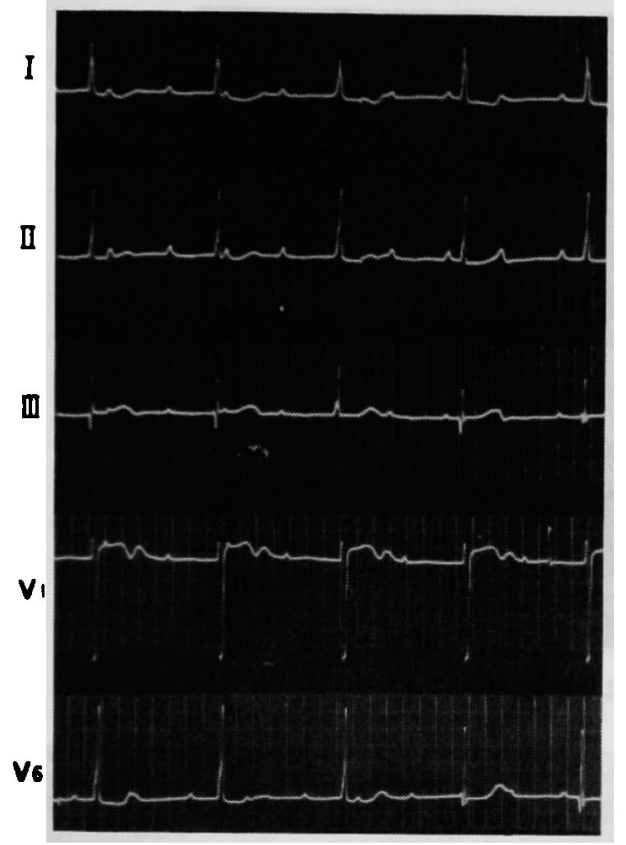

図 1 症例 1 の心园

ノーゼおよび浮腫は認められない，胸部では Erbに Levine 2度の収縮期雑音を聴取する. 腹部では，肝・脾 は触知しない，右大状在静脈より一時的ベーシング電㮌 が挿入されている.

柍奋成拄：血液および血液化学検査所見には異常は認 められない. 胸部レ線写真 ; 心胸廊比 $60 \%$ で心払大が 認められるが，肺血管陰影の増強はない，心電図（図 1）；完全房室プロックを示す. QRS 幅は0.08sec で ある. 心朠カテーテル検査; 異常所見は認められない. 以上の所見より合併心奇形を伴わない先天性房室ブロ ククと䛦断した．PM 植込み前に至適心拍数を検討し た. 至道心拍数を最大心拍出量を示す心拍数とすると， 至意心拍数は80/分となった. 昭和52年 4 月, 助膜外 PM
植込みを施行した。

手術不見：全身麻醉下に左前側方切開，第 5 肋間で開

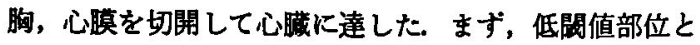
判定した左心室心尖部に小児用心㬳単極電極 (CPI model 4311) を梿着した。次いで，㑡胸部の胸壁肋膜を剩 離して助膜外に PM ポケットを作製した，電極と PM 本体 (Intermedics model 223，レート80/分) を接続し, PM 本体をこのポケット内に収納固定し，閉胸した（図 2 ).

街後龵過：経過は良好であった. 術後の胸部レ線写真 （图 3）；PM 本体情左胸邡内に植込ま九ており，心胸 麻比は53\%に減少した。なお，術中に採取した心筋の電 顕所見では異常所見は認められず，特発性先天性完全 房室ブロックと考えられる.

正例 2

思者：15歳，男.

家族歴，既往歴：特記すべきことはない.

現病暦: 昭和48年, 8 歳の時, 当科で不完全型心内膜 床欠損症の手術をらけた，術後，完全房室ブロックを認 め, 一時的ベーシングを行った. 一時的ベーシングを中 止しても特に愁訴がないため， $\mathbf{P M}$ 植込みを行らこと なく，外来通院で程過を観察していたか，心払大および 肝隀脹か：次第に増強するため， PM 植込みの適応とし て，昭和52年 4 月，12歳の時，再入院した。

入院時所見 : 身長 $144 \mathrm{~cm}$ 体重 $35.5 \mathrm{~kg}$ 脈拍数は49/分, 整である. 血圧 $94 / 64 \mathrm{mmHg}$. 胸部では心尖部に Levine 2 度の収縮期雑音を聴取する. 腹部では肝が 3 横指触知 された。浮腫は認められない。

挨查成暴：血液，血液化学検查所見には異常は認めら れない. 胸部レ線写真; 心胸廊比は68\%で心扗大を認め る. 心電図 (図4)；完全房室ブロックを示す. 至遠心 拍数を症例 1 と同様に検討し, ベーシングレートは70/ 分と決定した. 症例 1 と同様の肋膜外 PM 植込みを行

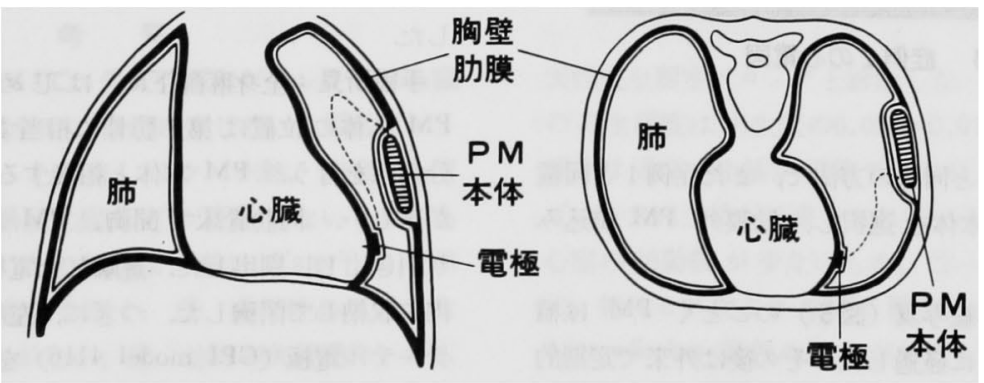

因 2 手赫方法 


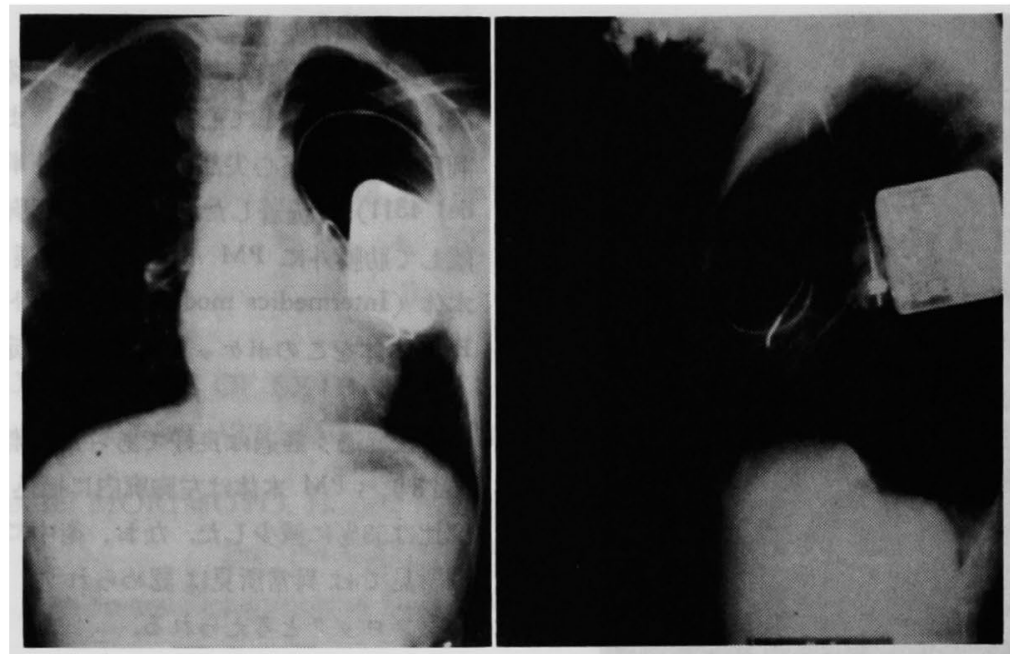

图3正例 1 の胸部レ楾写亲

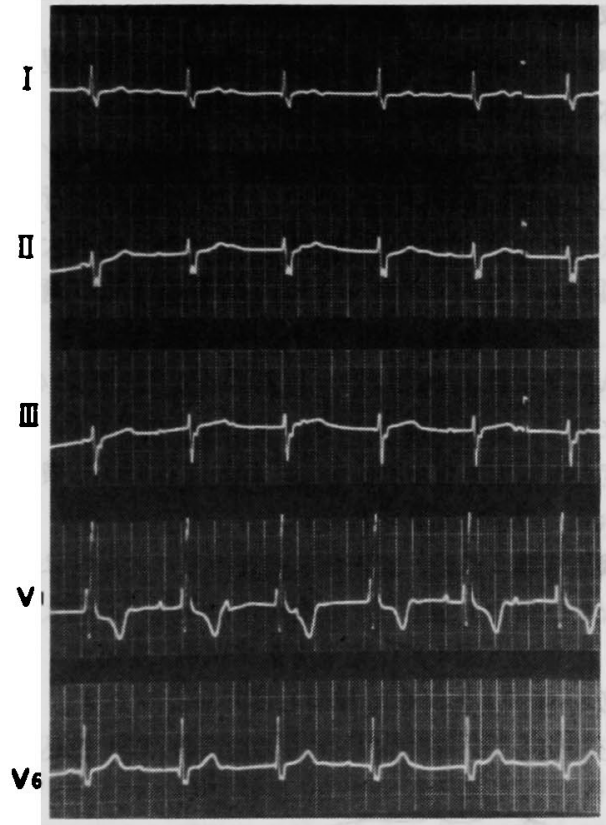

図4 应例 2 の心露図

らことにした.

手術开見：症例 1 と同様の方法で，また症例 1 と同種 の電楩および PM 本体を選択し, 助膜外 PM 植込み を行った.

郝後経過：胸部レ線写真（図5）のごとく $\mathrm{PM}$ は植 込をれており，良好に経過した．その後は外来で定期的 に診察を行っていた。
昭和55年 1 月，15歳，自宅で特に馀因なく，突然失神 発作が出現，脈拍数が 約50/分に減少しているのに 気付 き，直ちに当科に入院した。

入院時所見：身長 $163 \mathrm{~cm}$, 体重 $54.5 \mathrm{~kg}$ 意識は 明膫で ある. 心拍 (脈拍) 数は72/分で，背臥位にすると，心

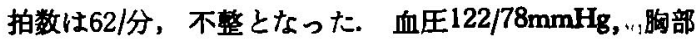
で双收期心雜音 (2/6) を聴取するはかに，異常所見 は認められない。

模查所見 : PM system tester (CPI model 2200)の データーは異常なく，PM 本体の故障は認められない。 胸部レ線写真 (図 6)：電極をみると，電極先端 (tip) に断線が認められる. 以上の所見より，電極の不完全断

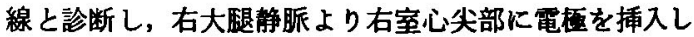
て，直ちに一時的ペーシングを開始した．今後の方針と しては, 患者は成長して体格は大きくなっており，胸麻 内 PM 植込みは必要ではないと判断し，断線電檑は胸 腔内に放固, 肋瞙外に植込まれた PM 本体は剔出し て，新たに経静脈電極による PM 植込みを行らことと した

手術所見：全身麻醉下に，はじあに左前側方切開， PM 本体の位置は第 7 肋骨飞相当するので，同骨の部 分切除を行う。 PM 本体と相接する 同助骨床は石灭化 が著しい，同肋骨床で開胸，PM 本体をボヶット内よ り引き出し，剔出した，遊離した電極の一部はポヶット 内に収納して閉胸した，つぎ，左觔側皮静脈より，カ テーテル電極 (CPI model 4116) を右室心尖部に樱入 させ, PM 本体 (CPI model $505 レ ー ト 72 /$ 分) は左前 


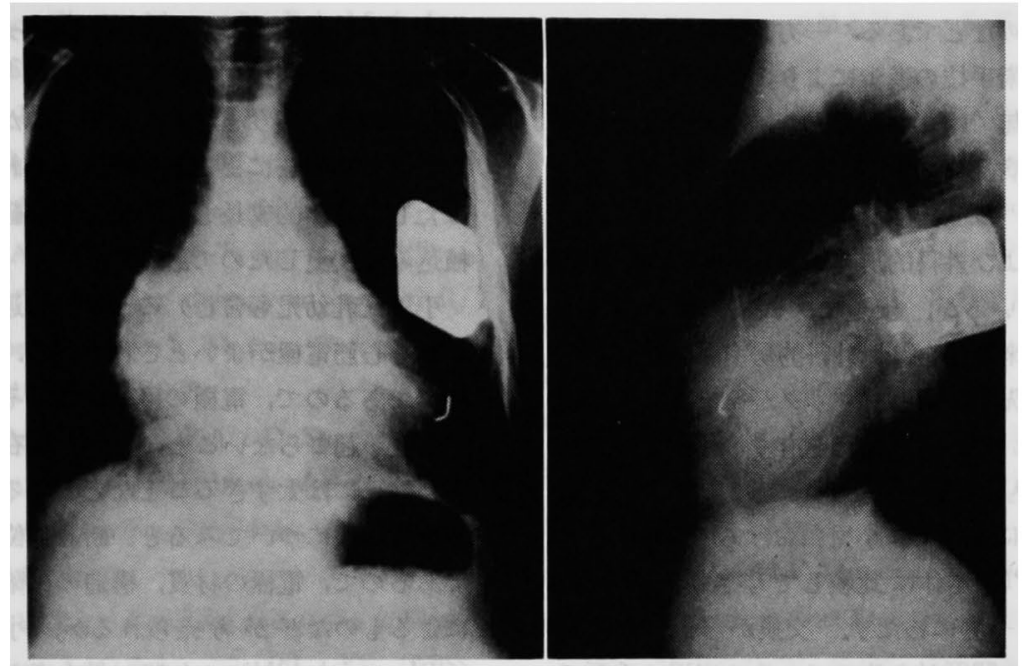

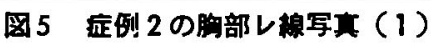

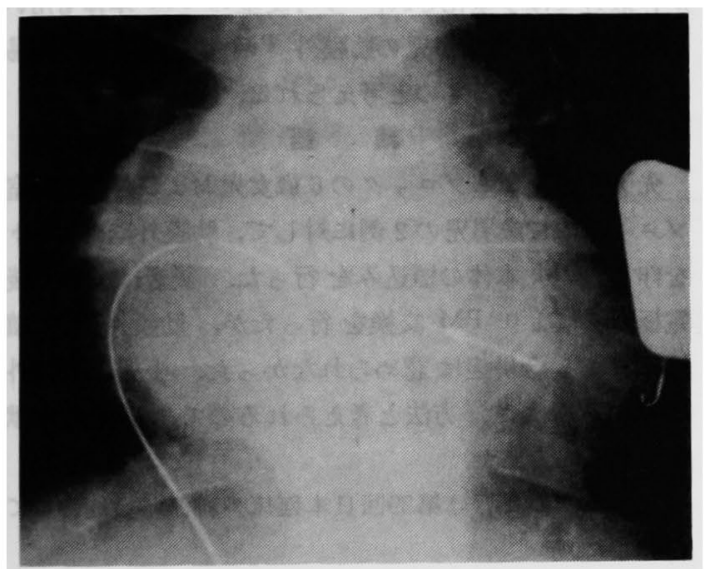

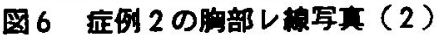

\section{的壁に植込んだ。}

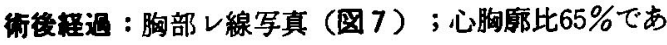
る. 合併症も認められず，释過は良好である。

\section{考察}

B室プロックについて : 先天性房室ブロックとは心缄 の先天性形成異常に伴い, 自然に生じている房室ブロッ クで，シフテリア，心笳炎，リウマチ熱，梅毒，心室 中隔基部の冠状動脈硬化症などの既往がないものであ る(12) とされている. その診断は一般に Yater")の規準 （1）若い年齿で徐脈を示す. (2) 先天性心疾患の合 併，(3) 感染の既往がない，(4) 幼時の失神発作）が広 く用いられている. 症例 1 は臨床および検查所見より先

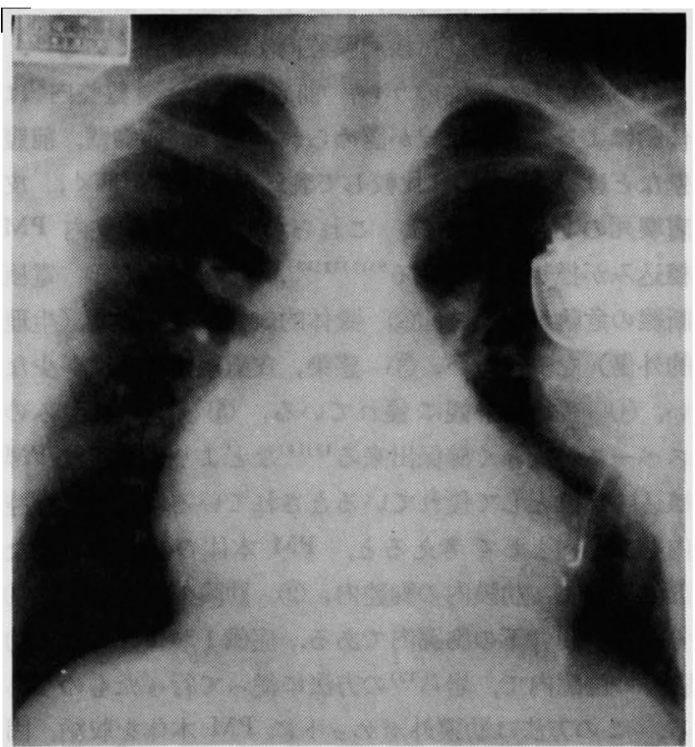

因 7 症例 2 の胸部レ線写共（3）

天性完全房室プロックと診断した. 先天性房室ブロック の発生頻度は出生児の0.005 0.01\%である“． その大 部分は通常の生活が可能であるか，つぎに述へる房室 ブロックは予後が不良とされている56). すなわち，(1) 心室の拍動数が少ないもの，(2) QRS 波幅が広いも の，特にヒス束より末梢に障害が認められるむの，(3) Adams-Stokes 発作の 既往があるるの，(4) 薬物あるい は運動負荷の反応に乏しいもの，(5) 先天性心疾患，心 
不全を合併するるのなどである．一方，外科的局室ブロ ックは，最近の手術手技の進歩に上り，その発生は減少 したとはいえ，皆無ではないのであり，その予後は不良 とされ放置すれば病院死あるいは遠隔死が認められる” のである. Glenn" は先天性房室ブロックで予後不良と されているものおよび外科的局室ブッックが PM 植込 みの適応とされているか，安全な，長期におよぶぺー シンクが完全に出来るならば，外科的房空ブロックのみ ならず，すへてての先天性房室ブロックがペーシングの道 応となると述へている．自覚症状を有する症例 1 扣よび 症例 2 はM 植込みの道応とされた。

PM 植込み部位について：小览における PM 植込み 部位は，身体が PM 本体に比較して小さい，身体の 成長，PM 使用が一生にわたり，交換が多い，全身的 運動が激しいなどの問題があるので，その選択は重要で ある. 小児の PM 植込み部位は Lindesmith ら”の述 べているごとく，前胸壁，前腹塈，胸肱内，横隔膜下拧 よび骨盤腔内があり，後腹膜沿内も報告されている ${ }^{10)}$.

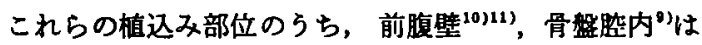
体動に上る電極の断線か認められ，また，前胸壁，前腹 壁などはPM 本体に比較して乳幼児では壁が薄く，皮 闰㙘死の危険性がある.これらのことより胸晖内 PM

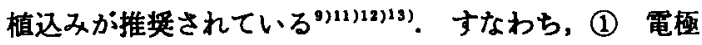
断線の危険が少ない，(2) 身体的成長に伴う影謷（生理

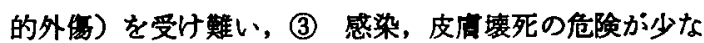
い, (4) 美容的外䍃に優れている，(5) PM 植込 みの スベースが大きく確保出来る(3)101などより胸腔内は PM 植込の部位として優れているとされている．さてて胸傕 内を胸廊内として考えると，PM 本体の植込石可能な 部位は, (1) 助膜内の胸脄内, (2) 肋膜外の胸廊内, (3) 骨膜外，助骨下の胸倣内である. 症例 1 および 2 は, 肋 膜外の胸㢌内で, 岩ら ${ }^{12)}$ の方法に従って行ったすのであ る. この方法は肋膜外ポケットに PM 本体を収納, 固 定して，PM 本体の胸腔内脱出を予防するため，胸腔 内植込みて認められる $\mathrm{PM}$ 本体の胸㭠内移動あるいは

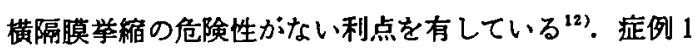
および2においても，肋獏外ボケット作製および PM 本体収納，固定は容易に施行可能であり，PM 本体の 胸腔内脱出は認められなかった. 症例 2 は電極断線のた

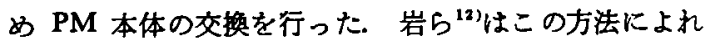
ば，PM 本体交換時には非開胸的に，肋膜外にて容易 に行らことが出来ると述へているが，症例2においては $\mathbf{P M}$ 本体周囲は石灰化を伴う被包を認め，開胸となり，
PM 本体交換は容易とはいえなかった，すなわち，前 胸壁あるいは前腹壁なとに比校して PM 本体交換には 多少の困難を伴うと考えられる. しかし，症例 2 におい ては，この方法による愁訴は認められず，充分な目的を はたし，身体的成長を認めたため，経静脈電極，前胸壁 植込みに変更したのである.

小児（乳奻児す含む）の $\mathrm{PM}$ 植込みには経静脈電栖 よりす心筋電極がよいとされている.心筋電極は固定が 確実であるので，電極の移動およびそれによるぺーシン ク不全が起こらないこと，また，現在の経静脈電極は小

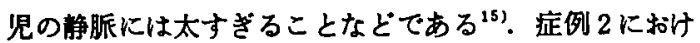
る電極断線についてみると，断線部位が電極先端 (tip) であるので，電極の材筫，構造の欠陥あるいは手術手技 によるものなどが考えられるが，小児用心箭単極電梗 (CPI model 4311) の欠陥が最も考えられた。

PM 本体は電池寿命の長いリチウム電池が用いられた か，最近で恃小型化され，多可変型の PM 本体む用い られているので，小児の肋膜外 PM 植込るはより容易 に安全に行い得るむのと考兄られる.

\section{結 语}

先天性完全房室ブロックの6 歳女児および外科的房室 ブロックの12歳男児の 2 例に対して, 肋膜外にボヶット を作り，PM 本体の植込みを行った。後者は約 3 年後 電極断線により PM 交換を行ったか，肋膜外 PM 植 込子による合併症は認められなかった，小坚の肋膜外 $\mathbf{P M}$ 植込みは上い方法と考えられるので，若干の文献 を加えて報告した。

(本論文の要旨仕第39回日本臨床外科医学会総会にて 発表した)

\section{文献}

1) Lev, M., Fiedding, R.T. and Zalske, D.: Mixed levocardia with ventricular inversion (corrected transposition) with complete atrioventricular block. Am. J. Cardiol., 12: 875883, 1963.

2）門間和夫, 大島正浩, 大国真彦 : 先天性完全房 室ブロックの臨床的観察, 日坚誌. $70 ： 395-$ 402, 1965.

3) Yater, W.M., Lyon, J.A. and McNabb, P.E.: Congenital heart block. J.A.M.A., 100: 18311937, 1933.

4) Swiderski, J.: Permanent advanced (II-III) atrioventricular block in children: Clinical 
and electrocardiographic study. Pol. Med. J., $7: 600-616,1968$.

5) Nakanura, F.F. and Nadas, A.S.: Complete heart block in infants and children. New England J. Med., 270: 1261-1269, 1964.

6) Trusler, G.A., Mustard, W.T. and Keith, J.D.: The role of pacemaker therapy in congenital complete heart block. J. Thorac. Cardiovasc. Surg., 55: 105-111, 1968.

7) Lauer, R.M., Ongley, P.A., DuShane, J.W. and Kirklin, J.W.: Heart block after repair of ventricular septal defect in children. Circulation, 22: 526-534, 1960.

8) Glenn, W.W.L.: Cardiac pacing in infants and children. Ann. Surg., 22: 605-606, 1976.

9) Lindesmith, G.G., Stiles, Q.R., Meyer, B.W., et al.: Experience with an implantable synchronous pacemaker in children. Ann. Thorac. Surg., 6: 358-364, 1968.

10）浅井康文, 藤堂景茂, 田中信行他：小児期ペー
スメーカーの植克込み，胸部外科，29：535一 $539,1976$.

11) Kahn, D.R., Stern, A., Sigmann, J. and Sloan, H.: An emergency method of handling blocken pacemaker wires in children. Amer. J. Cardiol., 15: 404-406, 1965.

12) 岩 喬, 三崎拓郎, 川筋道雄他 : 乳幼児のヘ 一スメーカー胸膜外植え込み, 胸部外科, 29 : $264-248,1976$.

13）鬼頭義次，藤田媇，内藤泰顕他：小児胸部内 ベースメーカー植込み術の検討, 人工搭器 9 : $16-19,1980$.

14) Lynch, M.F., Jensen, N.K. and Urdaneta, L.: Permanent cardiac pacemakers implanted in the pleural space. J. Thorac. Cardiovasc. Surg., 76: 101-107, 1978.

15) Liu, L., Griffiths, S.P. and Gerst, P.H.: Implanted cardiac pacemakers in children. Am. J. Cardiol., 20: 639—647, 1967. 